\title{
Effects of Seeding Rates and Nitrogen Fertilization on Seed Yield, Oil Content and Yield Components of Linseed (Linum usitasissimum L.) in the Highlands of Bale
}

\author{
Reta Dargie*, Tamiru Meleta, Kissi Wakweya \\ Oromia Agricultural Research Institute, Sinana Agricultural Research Center, Bale-Robe, Ethiopia \\ Email address: \\ bardargie@gmail.com (R. Dargie) \\ ${ }^{*}$ Corresponding author \\ To cite this article: \\ Reta Dargie, Tamiru Meleta, Kissi Wakweya. Effects of Seeding Rates and Nitrogen Fertilization on Seed Yield, Oil Content and Yield \\ Components of Linseed (Linum usitasissimum L.) in the Highlands of Bale. American Journal of Plant Biology. \\ Vol. 5, No. 3, 2020, pp. 45-49. doi: 10.11648/j.ajpb.20200503.13
}

Received: September 30, 2020; Accepted: October 16, 2020; Published: October 26, 2020

\begin{abstract}
A significant number of studies have been published on linseed husbandry in other countries but there is limited information on linseed production in the country. Due to such gaps, the experiment was conducted at two locations in Bale, south eastern Ethiopia (Sinana and Agarfa) to study effects of seeding rates and nitrogen fertilizations on linseed performance for three consecutive years (2016-2018). The treatments were four rates each of nitrogen $\left(0,23,46\right.$, and $\left.69 \mathrm{~kg} \mathrm{~N} \mathrm{ha}^{-1}\right)$, and seeding rates $\left(20,30,40\right.$, and $\left.50 \mathrm{~kg} \mathrm{ha}^{-1}\right)$ laid out in factorial arrangement of randomized complete block design (RCBD) with three replications. Linseed variety 'Jitu' was used as a test crop. The main effect of nitrogen and seed rates at Sinana was not significantly affected $(\mathrm{P}<0.05)$ most of the studied parameters probably due to relatively high accumulation of nitrogen in the soil and conducive environmental condition. However, the study conducted at Agarfa using similar methodology was significantly affected by the studied factors. This could be due to low to medium soil nitrogen status of the study site. Accordingly the result of the experiment at Agarfa revealed that applying $23 \mathrm{~kg} \mathrm{~N} \mathrm{ha}^{-1}\left(50 \mathrm{~kg} \mathrm{ha}^{-1} \mathrm{UREA}\right)$ when $20 \mathrm{~kg} \mathrm{ha}^{-1}$ seed rate in row planting were given the highest marginal rate of return. However further investigation has to be carried out on farmers' field in order to further confirm the present results.
\end{abstract}

Keywords: Economic Analysis, Linseed, Nitrogen, Nitrogen Status, Seed Rate, Yield

\section{Introduction}

Linseed is suited to a wide range of soil types but establishment can be difficult on heavy clay soils, as soils of a gravelly or dry sandy nature, which has to be avoided. A fine tilth and adequate moisture are required to ensure good establishment. Linseed requires cool temperature during its growing period for better yield. It prefers dry and sunny weather with well-distributed moderate rain over the growing season [5]. Linseed is grown in areas susceptible to frost because it has the ability to tolerate frost damage. On the basis of growth habit, two types (long stemmed and short stemmed) are recognized. Long stem linseed produces a high quality fiber but the oil content of the seed is relatively low. On the other hand, short-stemmed linseed bears larger seeds of high oil content and has branching tendency (Kaul, 1960).
The Bale highlands are one of the potential areas for the production of highland oil crops in Ethiopia, and linseed is the main oil crop grown in the zone. Regarding its future prospect, however, it can be envisage that the need for large scale production of this potential oil crop is eminent, particularly with the advent of state farms and farmers producers cooperatives so as to satisfy the ever-increasing domestic demand for oil and moreover ample production for export. In general, with the present national trend of agricultural diversification, linseed commands increased research interest focused on the cultural aspect of different varieties. Crop production could be increased either by improving the inherent genetic potential of the crop or through application of better agronomic management, such as use of optimum plant density and fertilizer.

Nitrogen fertilization is one of the most important 
agronomic practices for linseed production because there is a positive response to $\mathrm{N}$ but the overall response is less than that have seen in crops like barley, oilseed rape or wheat [7]. Plant density is a major factor determining the ability of the crop to capture resources and generate yield. It can be developed by using a suitable seeding rate. As the plant density increases, the competition for resources especially for nitrogen also increases that badly affect the ultimate yield. Provision of additional nitrogen can be hypothesized to further enhance the yield by increasing plant population but up to an optimum level. Further higher nitrogen can lead to the lodging of plants at higher seed rate [9].

Current national seeding rate recommendations for linseed production is $25 \mathrm{~kg} \mathrm{ha}^{-1}$ for row planting and 30 to $40 \mathrm{~kg} \mathrm{ha}^{-1}$ for broadcasting in Ethiopia. On the other hand, national fertilizer recommendation for linseed production is $23 / 23 \mathrm{~kg}$ $\mathrm{ha}^{-1} \mathrm{~N} / \mathrm{P}_{2} \mathrm{O}_{5}$. The same recommendations have been followed for linseed production and trials execution under different research stations. But, several farmers often broadcast more than double and triple rates for linseed production [2]. The same holds true with respect to linseed growing area of Bale highlands.

A significant number of studies have been published on linseed husbandry in other countries but there is limited information on linseed production in the country, especially on the performance of improved cultivars. None of the recommended linseed varieties were evaluated for the combined effect of seed rate and nitrogen fertilizer response in the study area. The introduction of high yielding linseed genotype accompanied with improved production technology packages like optimum $\mathrm{N}$ fertilization with optimum planting density could markedly increase productivity per a given hectare. Therefore, the present study was initiated with the objective of determining the optimum plant density and optimum nitrogen fertilization for improved linseed genotype.

\section{Materials and Methods}

The experiment was conducted on research field of Sinana Agricultural Research Center (SARC) and Agarfa, in the highlands of Bale, South-eastern Ethiopia during the main cropping season of 2016, 2017, and 2018. Linseed variety 'Jiituu' which was released by Sinana Agricultural Research Center was used for the experiment. The experiment was consisted of four rates each of nitrogen $(0,23,46$, and $69 \mathrm{~kg}$ $\left.\mathrm{N} \mathrm{ha}^{-1}\right)$, and seeding rates $\left(20,30,40\right.$, and $\left.50 \mathrm{~kg} \mathrm{ha}^{-1}\right)$ and laid out in factorial arrangement of randomized complete block design (RCBD) with three replications. A field layout was prepared and the treatments were assigned randomly to each plot within a block. The replications, blocks and experimental units were separated by $1.5 \mathrm{~m}, 1 \mathrm{~m}$, and $1 \mathrm{~m}$ respectively. Seeds were sown using row planting. Each plot consisted of 10 rows $20 \mathrm{~cm}$ apart and $4 \mathrm{~m}$ in length. The outer most two rows on both sides of each plot and $0.25 \mathrm{~m}$ length on each side of a row was served as a border. The remained net plots were used for data collection.

Soil samples were taken in a zigzag pattern from five sampling spots of the entire experimental field at $0-30 \mathrm{~cm}$ depth using an auger before sowing. The composite soil samples were prepared by quartering and air-drying at room temperature, ground using a pestle and a mortar and allowed to pass through a $2 \mathrm{~mm}$ sieve. Working samples were obtained from bulk sample and analyzed for total nitrogen, available $\mathrm{P}$, cation exchange capacity (CEC), $\mathrm{pH}$.

\section{Results and Discussions}

\subsection{Soil Chemical Properties}

The results of soil analysis (Table 1) showed that the soil reaction of the experimental sites were moderately neutral at Sinana and Agarfa, where the $\mathrm{pH}$ was 6.83 and 6.7, respectively This indicates that the soil reaction of the experimental sites is suitable for optimum growth and yield of most crops. According to Adugna [3] (2007), linseed will not perform well on soils with $\mathrm{pH}$ less than 5.0 or above 7.0 , which show that the crop is sensitive to both soil acidity and alkalinity. The CEC value of the soil was high at Agarfa and very high at Sinana; this indicates that the soil has relatively high capacity to hold nutrient cation and supply to the crop. The experimental soil is medium in available $\mathrm{P}$ at Sinana and Agarfa where 10.12 and 11.7 respectively. Data also indicated that the soils of the experimental sites had Medium total $\mathrm{N}$ which means fertilizer addition may increase growth and yield. However, Agarfa has lower total $\mathrm{N}$ as compared to Sinana. Therefore more response is expected from Agarfa.

Table 1. Chemical properties of the experimental soil before planting.

\begin{tabular}{lll}
\hline Parameters & Sinana & Agarfa \\
\hline Chemical Properties & & \\
pH in water $(1: 2.5)$ & 6.83 & 6.7 \\
CEC (cmol. $\left.(+) \mathrm{kg} \mathrm{soil}^{-1}\right)$ & 48.56 & 37.38 \\
Total N (\%) & 0.18 & 0.16 \\
Av. P (ppm), Olsen & 10.12 & 11.7 \\
\hline
\end{tabular}

\subsection{Effect of Seeding and Nitrogen Rates on Yield and Yield Components of Linseed at Sinana}

This experiment was conducted for the last three years (2016/17, 2017/18, and 2018/19 cropping season), the $2017 / 18$ was damaged due to chemical drift from Oromia Seed Enterprise (OSE), the remaining years required field data were collected and analyzed (Table 2). The combined analysis result over years showed that the main effect of seeding rates had significant $(\mathrm{P}<0.05)$ effect on number of tillers per plant, number of capsules per plant and no significant response was observed on days to $50 \%$ emergence and flowering, days to physiological maturity, plant height, number of primary branches and secondary branches per plant, number of seeds per capsule, biological yield $\left(\mathrm{kg} \mathrm{ha}^{-1}\right)$, seed yield $\left(\mathrm{kg} \mathrm{ha}^{-1}\right)$, thousand seed weight, percent oil content and harvest index. On another hand, the main effect of nitrogen rates had significant effect only on number of primary and secondary branches per plant where the remaining studied parameters were not significantly affected 
by the main effect of nitrogen rates. The two factors were not interacted to influence the studied parameters. However, response of linseed to population density was low compared to its responses to nitrogen rates. Because of better growing weather conditions and medium soil nitrogen level the formation of yield components is not influenced by the variation of seeding rates and also by the variation of nitrogen rates supply. Linseed able to compensate the yield differences of different plant population through the single yield component of pods per plant unit area as a result yield per unit area was constant over the range of densities tested. When sown at wide row spacing linseed compensates for low plant stands through extensive branching and increased plant size (Hassan and Leitch 2000). Linseed responds well on lower soil $\mathrm{N}$ levels. At sites where the $\mathrm{N}$ level was high, there was a limited response of linseed to extra N (Grant et al., 1999). Different reports by different researchers revealed that seed yield of linseed varied with site and year without showing a constant trend and some studies points to a limited response to nitrogen application when soil nitrate levels are high. The study area had medium soil N. In such a situation, the use of fertilizer on linseed would normally be unnecessary and the use of nitrogen fertilizer undesirable for oilseed production.

In general, linseed responds when grown on fertile soils. A combination of soil test and cropping history should be followed in the linseed fertility program. Application of high external fertilizer rates should not be done on fertile soil unless prior testing the soil.

Table 2. Effect of seeding rates and nitrogen fertilizer rates on seed yield, oil content and yield components of linseed at Sinana, 2016 and 20018 (Combined).

\begin{tabular}{|c|c|c|c|c|c|c|c|c|c|c|c|c|c|c|}
\hline & DE & DFL & DPM & NTL & PHT & NPB & NSB & NCP & NSC & BYD & SYD & TSW & OCC & HI (\%) \\
\hline \multicolumn{15}{|c|}{ Seeding Rate $\left(\mathrm{kg} \mathrm{ha}^{-1}\right)$} \\
\hline 20 & 9.0 & 78.5 & 121.46 & $1.9 \mathrm{a}$ & 84.2 & 5.2 & 2.3 & $19.2 \mathrm{a}$ & 7.88 & 6744.8 & 1915.2 & 5.9 & 38.6 & 28.4 \\
\hline 30 & 7.1 & 78.29 & 121.04 & $1.5 \mathrm{ab}$ & 85.6 & 4.9 & 2 & $18.2 \mathrm{ab}$ & 8.09 & 7456.6 & 2068.5 & 5.8 & 37.4 & 27.6 \\
\hline 50 & 6.2 & 76.96 & 121 & $1.4 \mathrm{~b}$ & 84.7 & 4.8 & 1.7 & $16.2 \mathrm{~b}$ & 8.37 & 7569.4 & 1990.6 & 5.8 & 39.5 & 26.3 \\
\hline $\mathrm{LSD}_{0.05}$ & ns & ns & ns & 0.21 & $\mathrm{~ns}$ & $\mathrm{~ns}$ & ns & 0.95 & ns & $\mathrm{ns}$ & $\mathrm{ns}$ & $\mathrm{ns}$ & $\mathrm{ns}$ & $\mathrm{ns}$ \\
\hline \multicolumn{15}{|c|}{ Nitrogen $\left(\mathrm{kg} \mathrm{ha}^{-1}\right)$} \\
\hline 23 & 7.3 & 77.5 & 119.79 & 1.5 & 84.7 & $5.1 \mathrm{ba}$ & $2 \mathrm{ba}$ & 17.9 & 8.42 & 7239.6 & 2033.8 & 5.9 & 40.6 & 27.9 \\
\hline 46 & 7.1 & 77.96 & 121.25 & 1.6 & 86.1 & $4.7 b$ & $1.8 \mathrm{~b}$ & 17.1 & 7.96 & 7369.8 & 2028.7 & 5.8 & 39.6 & 27.6 \\
\hline 69 & 7.8 & 78.42 & 122.17 & 1.8 & 84.9 & $5.2 \mathrm{a}$ & $2.4 \mathrm{a}$ & 18.8 & 8.1 & 7265.6 & 1940.8 & 5.8 & 38.9 & 26.6 \\
\hline $\mathrm{LSD}_{0.05}$ & ns & ns & ns & $\mathrm{ns}$ & ns & 0.2 & 0.36 & ns & ns & ns & ns & $\mathrm{ns}$ & ns & $\mathrm{ns}$ \\
\hline CV (\%) & 11.2 & 2.1 & 2.1 & 42.1 & 5.2 & 13 & 43 & 17 & 15.1 & 18.9 & 11.8 & 2.3 & 4.7 & 9.2 \\
\hline
\end{tabular}

Keys: $\mathrm{DE}=$ Days to Emergence, $\mathrm{DFL}=$ Days to Flowering, DPM=Days to Physiological Maturity, NTL= Number of Tillers per Plant, NPB=Number of Primary Branches per plant, NSB=Number of Secondary Branches per plant, NCP=Number of Capsules per plant, BYD=Biological Yield, $\mathrm{SYD}=\mathrm{Seed}$ Yield, $\mathrm{TSW}=$ Thousand Kernel Weight, HI $(\%)=$ Harvest index, OCC= Oil content, $\mathrm{S}=$ Significant, Ns=Non-significant.

\subsection{Effect of Seeding and Nitrogen Rates on Yield and Yield Components of Linseed at Agarfa}

Crop yield is a complex character depending upon a large number of environmental, genetic, morphological and physiological characters and their interactions. Combined years in Agarfa have shown that significant differences $(\mathrm{P}<0.05)$ of seed rates were observed on number of tillers per plant, primary branches per plant, secondary branches per plant, capsules per plant, biological yield $\left(\mathrm{kg} \mathrm{ha}^{-1}\right)$, seed yield $\left(\mathrm{kg} \mathrm{h} \mathrm{h}^{-1}\right)$ and harvest index. However significant $(\mathrm{P}<0.05)$ effects of seed rates were not observed on days to emergence, days to flowering, and days to physiological maturity, plant height, and number of seeds per capsule, thousand seed weight, and percent oil content. Njuguna et al.,[10] reported that seed rates had no significant effects on plant height, spikes $/ \mathrm{m}^{2}$ and thousand seed weight. The highest seed yield was recorded from $30 \mathrm{~kg} \mathrm{ha}^{-1}\left(1771 \mathrm{~kg} \mathrm{ha}^{-1}\right)$. Most parameters studied were not indicated neither linear increase nor linear decrease. The lowest seed rate $\left(20 \mathrm{~kg} \mathrm{ha}^{-1}\right)$ produced significantly higher yield components (Table 3 ) as compared to highest seed rates $\left(50 \mathrm{~kg} \mathrm{ha}^{-1}\right)$. This finding is in agreement with Lal et al.,[8] and Abd El-Mohsen et al. [1] as sited by AbebeDelesa, 2015who reported that increasing seed rate significantly decreased growth and yield attributes of linseed crop.

The combined analysis of variance over years in Agarfarevealed that nitrogen application rates significantly $(\mathrm{P}<0.05)$ affected days to flowering, number of tillers per plant, plant height, number of primary branches per plant, number of secondary branches per plant, number of capsules per plant, biological yield $\left(\mathrm{kg} \mathrm{ha}^{-1}\right)$, seed yield $\left(\mathrm{kg} \mathrm{ha}^{-1}\right)$, percent oil content and harvest index. Nitrogen fertilization is one of the most important agronomic practices for linseed production because there is a positive response to $\mathrm{N}$ but the overall response is less than that have seen in crops like barley, oilseed rape or wheat [7]. Number of capsules per plant, number of seeds per capsule, and seed yield of linseed cultivars was increased with increasing nitrogen levels [6]. High $\mathrm{N}$ fertilizer applications may give high yields, but often without improving the net economic returns. Excessively high applications of $\mathrm{N}$ fertilizer can cause problems because rank crop growth results in lodging and poor fiber yields in fiber flax and poor capsule production in linseed. On the other hand, significant differences were not observed for days to maturity, days to emergence, number seeds per capsule and thousand seed weight (Table 3). 
Table 3. Effect of seeding rates and nitrogen fertilizer rates on seed yield, oil content and yield components of linseed at Agarfa, 2006 and 2008 (Combined).

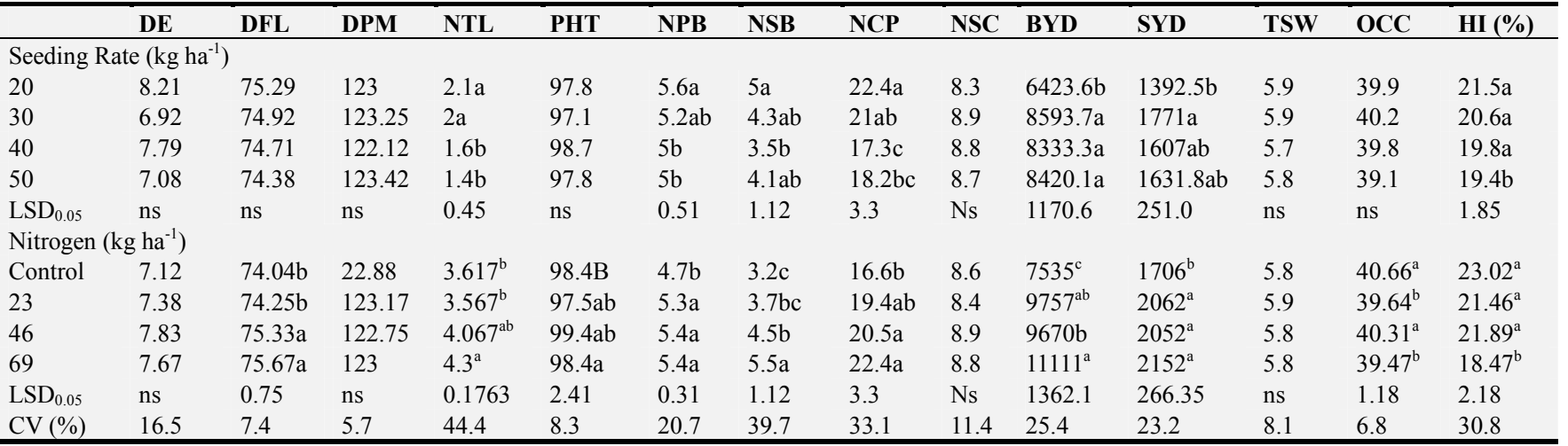

Keys: DE=Days to Emergence, DFL=Days to Flowering, DPM=Days to Physiological Maturity, NTL= Number of Tillers per Plant, NPB=Number of Primary Branches per plant, NSB=Number of Secondary Branches per plant, NCP=Number of Capsules per plant, BYD=Biological Yield, $\mathrm{SYD}=\mathrm{Seed}$ Yield, TSW=Thousand Kernel Weight, HI $(\%)=$ Harvest index, OCC= Oil content, $\mathrm{S}=$ Significant, Ns=Non-significant.

\subsection{Partial Budget Analysis}

Marginal analysis is an important step in assessing the results of on farm experiments before making recommendations. For this trial variable cost of seed and fertilizer was used for partial budget analysis. Marginal Rate of Return, which refers to net income obtained by incurring a unit input, was calculated by dividing the net increase in yield of linseed due to the application of each input to the total cost of each input applied at each rate. This enables us to identify the optimum rates of seed and fertilizer rates for linseed production.

For a treatment to be considered as a worthwhile option to farmers, the marginal rates of return (MRR) need to be at least between $50 \%$ and $100 \%$ [4]. Some scholars also suggested MRR of $100 \%$ as realistic. Thus, to draw farmers' recommendations from marginal analysis in this study, $100 \%$ return to the investment is reasonable minimum acceptable rate of return, since farmers' in the study area usually not apply $\mathrm{N}$ and broadcast double amount of seed rates and they did not much familiar with row seeding of linseed. The partial budget analysis in this study indicated that highest MRR $(1312.9 \%)$ was obtained by applying $23 \mathrm{~kg} \mathrm{~N} \mathrm{ha}^{-1}$ when $20 \mathrm{~kg} \mathrm{ha}^{-1}$ seed rate was used for row planting (Table 4). Therefore, application of $50 \mathrm{~kg} \mathrm{ha}^{-1}$ UREA $\left(23 \mathrm{~kg} \mathrm{~N} \mathrm{ha}^{-1}\right)$ with $20 \mathrm{~kg} \mathrm{ha}^{-1}$ seed rate in row planting were superior rewarding treatment and this levels can be recommended for farmers in Agarfa and similar agro ecology conditions.

Table 4. Partial and marginal budget analysis for seed and nitrogen rates combined years, 2016 and 2018 at Agarfa.

\begin{tabular}{|c|c|c|c|c|c|c|c|}
\hline Seed rate $\left(\mathrm{kg} \mathrm{ha}^{-1}\right)$ & Nitrogen $\left(\mathrm{kg} \mathrm{ha}^{-1}\right)$ & FYD $\left(\mathrm{kg} \mathrm{ha}^{-1}\right)$ & AYD $\left(\mathrm{kg} \mathrm{ha}^{-1}\right)$ & GB (ETB) & VC (ETB) & NB (ETB) & MRR (\%) \\
\hline 20 & 0 & 1285 & 1157 & 37014 & 580 & 36434 & 0 \\
\hline 30 & 0 & 1391 & 1252 & 40053 & 870 & 39183 & 947.931 \\
\hline 40 & 0 & 1494 & 1345 & 43029 & 1160 & 41869 & 926.207 \\
\hline 20 & 50 & 1813 & 1632 & 52208 & 1230 & 50978 & 1312.9 \\
\hline 50 & 0 & 1433 & 1290 & 41282 & 1450 & 39832 & \\
\hline 30 & 50 & 1113 & 1002 & 32065 & 1520 & 30545 & \\
\hline 40 & 50 & 1409 & 1268 & 40572 & 1810 & 38762 & \\
\hline 20 & 100 & 1555 & 1399 & 44784 & 1880 & 42904 & \\
\hline 50 & 50 & 1364 & 1227 & 39273 & 2100 & 37173 & \\
\hline 30 & 100 & 1499 & 1349 & 43166 & 2170 & 40996 & \\
\hline 40 & 100 & 1680 & 1512 & 48383 & 2460 & 45923 & \\
\hline 20 & 150 & 1397 & 1257 & 40229 & 2530 & 37699 & \\
\hline 50 & 100 & 1547 & 1392 & 44541 & 2702 & 41839 & \\
\hline 30 & 150 & 1893 & 1703 & 54506 & 2820 & 51686 & 600 \\
\hline 40 & 150 & 1726 & 1553 & 49698 & 3110 & 46588 & \\
\hline 50 & 150 & 1437 & 1294 & 41394 & 3400 & 37994 & \\
\hline
\end{tabular}

Keys: $\mathrm{FYD}=$ Field yield, $\mathrm{AYD}=$ Adjusted yield, $\mathrm{GB}=$ Gross benefit, $\mathrm{VC}=$ Variable cost, $\mathrm{NB}=$ Net benefit, $\mathrm{MRR}=$ Marginal rate of return.

\section{Conclusion and Recommendations}

The Bale highlands are one of the potential areas for the production of highland oil crops in Ethiopia, and linseed is the main oil crop grown in the zone. In general, with the present national trend of agricultural diversification, linseed commands increased research interest focused on the cultural aspect of different varieties. Crop production could be increased either by improving the inherent genetic potential of the crop or through application of better agronomic management, such as use of optimum plant density and fertilizer. Study was conducted using seed and nitrogen rates at Sinana and Agarfa to determine on growth and yield of linseed. The response of seed and nitrogen rates at Sinana 
was not significant probably due to relatively high accumulation of nitrogen in the soil and conducive environmental condition. Under nutrient sufficient and conducive environmental conditions plants in the range of studied factor levels did not interact or compete. Linseed responds well to nitrogen fertilizer application when available soil $\mathrm{N}$ is low. However, the study conducted at Agarfa using similar methodology was significantly affected by the factors. This could be due to low to medium soil nitrogen status of the study site. Accordingly the result of the experiment at Agarfa revealed that applying $23 \mathrm{~kg} \mathrm{~N} \mathrm{ha}^{-1}$ (50 $\mathrm{kg} \mathrm{ha}{ }^{-1}$ UREA) when $20 \mathrm{~kg} \mathrm{ha}^{-1}$ seed rate in row planting were given the highest marginal rate of return. Therefore, 23 $\mathrm{kg} \mathrm{N} \mathrm{ha}{ }^{-1}$ (50 kg ha ${ }^{-1}$ UREA) and $20 \mathrm{~kg} \mathrm{ha}^{-1}$ seed rates in row planting can be recommended At Agarfa area with similar soil nutrient status and agro ecology. However further investigation has to be carried out on farmers' field in order to further confirm the present results.

\section{References}

[1] Abd El-Mohsen AA, Abdallah AM, Mahmoud GO (2013). Optimizing and describing the influence of planting dates and seeding rates on flax cultivars under Middle Egypt region conditions. World Essays Journal/1 (2): 28-39.

[2] Abebe D, Birhane A, Workiye T, Adane C (2011). Prevalence of Weeds in Linseed Fields and Farmers Cultural Practices in Producing Linseed. In: Terefa G, Wakjira A and Gorfu D (eds.). Oilseeds: Engine for Economic Development.
[3] Adugna Wakjira, 2007. Linseed (Linumusitatissimum L.) pp. 108-115 in: van der Vossen H. A. M. and Mikilamo G. S. (Eds.) Plant Resources of Tropical Africa 14. Vegetable oils. PROTA Foundation, Wageningen, Netherlands/ Backhuys Publishers, Leiden, Netherlands, www.Prota.org.

[4] CIMMYT. 1988. From agronomic data to farmers recommendation: An economic training manual. Revised Edition. Mexico, D. F.

[5] Getinet Alemaw and Nigussie Alemayehu, 1997. Highland Oil Crops: A Three Decade Research Experience in Ethiopia. Research report No. 30. Institute of Agricultural Research, Addis Abeba, Ethiopia.

[6] Hussain, M. M. M. and Zedan, S. Z. A. 2008. Yield and quality of two flax varieties as affected by foliar spraying with potassium rates and nitrogen levels under sandy soil condition. Journal of Agricultural Sciences. Mansoura University. 33: 3937-3952.

[7] Lafond, G. P. 1993. The effects of nitrogen, row spacing and seeding rate on the yield of flax under a zero-till production system. Canadian Journal of Plant Sciences, 73: 375-382.

[8] Lal MR, Singh TK, Kumar R, Singh AK, Hari OM (2011). Production performance of linseed to fertility levels and seed rates in dry land conditions of Eastern Upper Pradesh. Ind. J. of Soil Conservation. 39 (3): 230-235.

[9] Nazir, MS., A. Jabbar, Z. Waheed, A. Gaffar and M. Aslam, 2000. Resonse of late sown wheat to seeding density and nitrogen management. Park. J. Biol. Sci., 3: 998-1001.

[10] Njuguna MN, Munene M, Mwangi HG, Akuja AK (2008). Effect of seeding rates and nitrogen fertilizer on wheat grain yield on marginal areas of eastern Kenya. Kenya Agricultural Research Institute-Njoro NPBRC. P. O. Njoro, Kenya. 